\title{
Investigating the Presence of Fisher Effect for the China Economy'
}

Utku ALTUNÖZ (http://orcid.org/0000-0002-0232-3108), Department of Business Administration, Sinop University, Turkey; e-mail: utku_al@sinop.edu.tr

\section{Çin Ekonomisi İçin Fisher Etkisinin Varlığının Analizi ${ }^{2}$}

\begin{abstract}
In economic science, Fisher effect is known as the long run relationship between interest rates and inflation rates. According to Fisher, when economy at the full employment, increase in inflation is fully reflects to the nominal interest rates. Fisher equation is used to formulate the relationship between inflation and interest rates. Equation stands out the evidence about money growing, inflation and rates. In this study, the validity of fisher effect for China was tested over the period 1996:01 2015:03, the long run relationship between nominal interest rate and inflation rate was examined by using ARDL Bounds Testing Approach which was developed by Peseran et al. Before ARDL, theoretical background of Fisher Effect was explained. Following the literature survey, stationary situations were tested by Augmented Dickey Fuller unit root test. After that Autoregressive-Distributed Lag Bounds Test was applied on variables. According to result of study, the presence of fisher effect in China was supported.
\end{abstract}

Keywords

: Interest Rate, Inflation, Fisher Effect, Error Correction Model, Cointegration Analysis, ARDL Bounds Test.

JEL Classification Codes : $\quad$ C12, C22, E31, E43.

$$
\text { Öz }
$$

Ekonomi biliminde Fisher Etkisi, uzun dönemli faiz ile enflasyon ilişkisi olarak bilinmektedir. Fisher'e göre, uzun dönemde milli gelir tam istihdam seviyesinde iken enflasyon oranında bir artış tamamen nominal faiz oranını etkileyecektir. Bu çalışmada, Çin için Fisher Etkisinin geçerliliği 1996: 01-2015: 03 dönemi için test edilmiştir. Nominal faiz oranı ile enflasyon oranı arasındaki uzun dönemli ilişki, Peseran ve arkadaşları tarafından geliştirilen ARDL Sınır Testi Yaklaşımı kullanılarak incelenmiştir. ARDL testi öncesinde Fisher Etkisi'nin teorik arka planı incelenmiştir. Literatür araştırmasının ardından Augmented Dickey Fuller birim kök testi ile seriler durağanlaştırılmış ve durağan serilere ARDL (Autoregressive-Distributed Lag Bounds) testi uygulanmıştır. Çalışmanın sonucunda Çin Ekonomisinde Fisher Etkisinin varlığına ulaşılmıştır.

1 This article is the revised and extended version of the paper presented in "Second International Annual Meeting of Sosyoekonomi Society" which was held by Sosyoekonomi Society and CMEE - Center for Market Economics and Entrepreneurship of Hacettepe University, in Amsterdam/The Netherlands, on October 28-29, 2016.

2 Bu makale Sosyoekonomi Derneği ile Hacettepe Üniversitesi Piyasa Ekonomisini ve Girişimciliği Geliştirme Merkezi tarafindan Hollanda'nın Amsterdam şehrinde, 28-29 Ekim 2016 tarihlerinde düzenlenen "Ikinci Uluslararası Sosyoekonomi Derneği Yıllık Buluşması"nda sunulan çalışmanın gözden geçirilmiş ve genişletilmiş halidir. 
Anahtar Sözcükler
: $\quad$ Faiz Oran1, Enflasyon, Fisher Etkisi, Hata Düzeltme Modeli, Eş

Bütünleşme, ARDL Sınır Testi.

\section{Introduction}

The interaction between inflation and nominal interest rates - which is known as Fisher effect or Fisher Hypothesis- is one of the most debated topics among economists. Recognition of the interaction and the validity of Fisher Effect is important for market efficiency and rationality. Changing of the decision of Institutions and policy decision makers about monetary policies effect the future decision of economic actors through inflation and interest rates. For this reason, inflation and interest rates underlie the stability programs.

In this study terms of Fisher hypothesis and Fisher effect was used instead of each other in order to show to the readers that both usage was same meaning. The reader that in the first part of this study, which examined the relationship of inflation and nominal interest rates in China, theoretical background of Fisher Effect was explained in the light of Fisher's study (1930). Following to explanation of the financial liberalization and economic development in China, study was supported by detailed literature survey. In the last part, fisher effect was tested by ARDL model and reached the fact that it is concluded that the Fisher hypothesis is valid in China for the relevant terms. The results obtained from the study about fisher effect in China shows that nominal interest rate and inflation rate are co integrated. It is understood that the Fisher effect is supported for China Economy.

\section{Theoretical Background of Fisher Effect}

Relationship between interest rate and inflation is one of the most discussed problems in economics. According to Fisher (1930), nominal interest rate will be equal to the sum of the expected inflation and real interest rate in same term. According to Fisher, gross national product will be at the full employment level in the long run term. Because of this fact, increase in inflation is reflected fully in, while real rates remain same. (Fama, 1975: 17). Fisher equation is used to formulate the relationship between inflation and interest rates. Equation is given below (Fisher, [1930] 1961: 27).

$$
i \equiv r^{*}+\pi
$$

where i symbolizes nominal rates, $r^{*}$ real rates and $\pi$ inflation.

In a similar way;

Simply, Fisher effect shows that nominal interest rates $\left(i_{t}\right)$ equal the sum of expected inflation $\left(\pi_{t}^{e}\right)$ and real interest rates $\left(r_{t}^{e}\right)$.

We can formulate fisher effect like below: 


$$
i_{t}=r_{t}^{e}+\pi_{t}^{e}
$$

Under the rational expectation assumption, expected inflation is equal to the sum of actual inflation rate $\left(\pi_{t}\right)$ and a random error term $\left(\varepsilon_{t}\right)$. Formulization is like below:

$$
\pi_{\mathrm{t}}^{\mathrm{e}}=\pi_{\mathrm{t}}+\varepsilon_{\mathrm{t}}
$$

$\left(\varepsilon_{t}\right)$ In equation (3) denotes error correction term which means Where EC is the error correction part of the model and measures the speed at which prior deviations from equilibrium are corrected.

In some sources, Fisher hypothesis is examined by three different approaches as domestic Fisher Hypothesis, international Fisher hypothesis and generalized Fisher hypothesis. Domestic Fisher hypothesis is described that nominal interest rate is equal to the sum of real interest rate and expected interest rate. But domestic Fisher effect cannot be valid always due to change in domestic policy effects the real interest rates. Under the ceteris paribus assumption, the relationships between nominal interest rate, real interest rate and inflation rate can show as equation (4) below (Akıncı \& Y1lmaz, 2016: 36):

$$
1+r_{t}=\frac{1+i_{t}}{1+\pi_{t}}
$$

In the equation (4), $i_{t}$ shows the nominal interest rate, $\pi_{t}$ shows the inflation rates and $r_{t}$ shows the real interest rate. By considering $r_{t}$, we can reach the equation (5) as below:

$$
r_{t}=\frac{i_{t}-\pi_{t}}{1+\pi_{t}}
$$

In the case where the denominator is ignored and the real interest rate is fixed, expected inflation of beginning period $\pi_{t}^{e}$ is the determinant of nominal interest rate. So equation (6) is obtained as below:

$$
i_{t}=r+\pi_{t}^{e}
$$

Second type of Fisher effect is known as generalized Fisher effect. It describes, the nominal interest rate differences between the two countries equals difference of inflation rate of mentioned countries. Under the assumption of $\mathrm{X}$ and $\mathrm{Y}$ countries, generalized Fisher condition shows as below:

In the equation (7) $i_{x}$ ve $i_{y}$ is respectively.

$$
i_{x}-i_{y}=\pi_{x}-\pi_{y}
$$

In equation (7), $i_{x}$ and $i_{y}$ respectively represent the nominal interest rates of $\mathrm{X}$ and $\mathrm{Y}$ countries, $\pi_{x}$ and $\pi_{y}$ respectively represent the expected inflation rate of $\mathrm{X}$ and $\mathrm{Y}$ countries. Because Fisher believe that monetary and real sector are independent, the real rate of return is determined by financial factors and the fiscal rate of return is determined by monetary 
factors (Akıncı \& Y1lmaz, 2016: 36). So that in equation (7) means in case of high expected inflation, nominal interest rate will be considerably higher.

Third type of Fisher effect is named international Fisher Effect which is explained the difference of nominal interest between two countries will reflect the information regarding the expected exchange rate changes in these countries. International Fisher effect consists of combining with generalized Fisher effect and relative purchasing power parity. Relative purchasing power parity is describing that expected inflation rates for both countries will be equal to the change in expected exchange rate. This situation shows as equation (8) below:

$$
\pi_{x}-\pi_{y}=\frac{s_{t+1}-S_{t}}{S_{t}}
$$

In equation (8), $S_{t}$ and $S_{t-1}$ respectively reflect current and next term spot exchange rates. When equation (7) and (8) is combined, international Fisher effect can be formed as equation (9) below:

$$
\pi_{x}-\pi_{y}=i_{x}-i_{y}=\frac{s_{t-1}-S_{t}}{s_{t}}
$$

According to equation (9), it can be said that countries with the high inflation rates causes the increasing of interest rates. As a parallel of this situation, exchange rate rises and National currency will lose value.

According to Hatemi-J and Irando (2008), despite the theoretical base, the Fisher hypothesis has not been powerfully encouraged empirically. Fama and Gibbon (1982), Huizinga and Mishkin (1986) and Kandel et al., (1996) reached that real interest rates were negatively concerned to the expected inflation rates. Nevertheless, great majority of economic literature accepts the Fisher Equation as stated in Fisher's original work. In this study, the Fisher effect will be tested by using 1996:01-2015:03 data sets for the China economy.

\section{Financial Liberalization and Economic Development in China}

The establishment of the People's Republic of China since 1949, China's economy has made rapid development. Especially since 1978 -the beginning of the reform and opening-up policy- China's economy it has grown over 9\%. In 2002, China's gross domestic product 1 trillion 400 billion USD. In mentioned year, china ranked $6^{\text {th }}$ following United States of America, Japan, Germany, Great Britain and France. The last 10 years, maintaining steady growth rate of $10 \%$, China became known 'century of our new global power'. 
Table: 1

Economic Indicators of China (2010-2015)

\begin{tabular}{|l|c|c|c|c|c|}
\hline INDICATORS & $\mathbf{2 0 1 0}$ & $\mathbf{2 0 1 3}$ & $\mathbf{2 0 1 4}$ & $\mathbf{2 0 1 5}$ & $\mathbf{2 0 1 5}$ (Estimated) \\
\hline Growth & 10.6 & 7.7 & 7.4 & 6.8 & 6.3 \\
\hline Investment/ Gross National Product & 47.2 & 46.5 & 46 & 44 & 43.4 \\
\hline Saving/Gross National Product & 51.2 & 48 & 48.1 & 47.4 & 46 \\
\hline Unemployment (\%) & 4.1. & 4 & 4.1 & 4.1 & 4.1 \\
\hline Inflation (\%) & 4.6 & 2.5 & 1.5 & 1.5 & 1.8 \\
\hline Current Balance/Gross National Product & 4 & 1.6 & 2.1. & 3 & 2.7 \\
\hline Increase in Export (\%) & 29.2 & 9.6 & 6.4 & 6.3 & 6.5 \\
\hline Public Debt (\%) & 36.2 & 39.3 & 40.7 & 42.8 & \\
\hline Budget Balance/Gross National Product & -1.2 & -1.1 & -1.1. & -1.9 & \\
\hline
\end{tabular}

Source: <http://www.mahfiegilmez.com/2015/08/cin-ekonomisi.html>, 28.09.2016.

According to Table 1, it is understood that investments and savings in China show a tendency to decrease. As a result of this situation, growth rate and current account surplus decrease. Beside, China prevents the unemployment problem by implementing the policies related to labor-intensive investments. In order to increase of falling growth rate, Chine implemented the expansionary fiscal policy. Because of this fact that China faced the growing budget deficit and growing public debt burden. This situation can be seen from Table 1. The most striking deterioration in the Table 1 is the export realizations. China's export growth rate has dramatically declined from 2010. Region economies such as Japan, Korea, Singapore, Hong Kong, Thailand, Taiwan, Malaysia, Indonesia, and Vietnam produce and sell the same productions. So that to become a rival to each other. According to Eğilmez (2015), Japan, one of the important rival of China began to lower the value of the Yuan through monetary expansion. Due to the strong yen, japan reclaimed the lost competitiveness against regional rivals. China's devaluation decision was taken in response to Japan's mentioned policies.

For many years, the United States of America blame China for keeping Yuan low levels and prompting the export.

In the region, in response to policies of devaluation and monetary easing by Central bank of Japan, China's Yuan Devaluations are thought as a battle of rates. In recent years, developments in China economy brought Financial Repression model on minds. According to McKinnon (1973) and Shaw (1973) claim that the opinion that a set of government regulations, laws, and non-market limitations block the financial mediator of an economy.

The policies that cause financial repression involve debt and ceiling of interest rate, high bank reserve requirements, capital controls, liquidity ratio requirements, limitation on market access into the financial area, limitation on credit using, and government ownership or domination of banks.

Slowing down of the economic growth in Euro Zone as a result of 2008 Global Crisis affect China economy badly. This situation caused decrease in demand for tradeable goods. Thanks to those developments, China authorities focused on increasing domestic demand. With the regulations and implementation of government, Chinese banks found an opportunity to use and make them use much more credits to their customers. 
China's central bank reduced to the benchmark interest rates and the required reserve ratio applying by banks to support the economy. In 2015 of August, Yuan was devalued by 4.6 by China's Central Bank. In the first weeks of 2016 after the Chinese central bank to reduce the reference rate unexpectedly, Yuan fell to its lowest level in last 5 years. Due to credit rationing, shadow banking in China went forward.

\section{Literature Survey}

Garcia (1993) tested the Fisher effect for Brazil economy during 1973-1990. Garcia tested the model with Brazilian data by using interest rate data on non-indexed certificates of deposit from a sample of major Brazilian banks. He reached that data was steady for with the Fisher effect.

Phylaktis and Blake (1993) teste the Fisher Effect theory for Mexico, Argentina and Brazil. Mentioned countries were selected as high-inflation economies. Phylaktis and Blake used unit root test and cointegration techniques. As a result of study, found existance alongrun relationship between nominal interest rates and inflation for Mexico, Argentina and Brazil.

Peng (1995) tested the fisher effect for OECD countries by using the data sets covering 1957-1994. The result of Peng's study, it was understood that there was a long run relationship between inflation and interest rates for France, the USA and England. Nevertheless, weak relationship existed for Germany and Japan.

Dutt ve Ghosh (1995) tested the existence of fisher effect for 1979:4 and 1993:2 for the Canadian Economy under the floating exchange rate regime. The authors concluded that the Fisher Effect was not valid for period they had examined.

Weidmann (1997) examined the Fisher Hypothesis for Germany by threshold co integration model. Mentioned study showed the full existence of Fisher hypothesis in Germany.

Carneiro, et al. (2002), used Johansen co-integration test the dates between 1980 and 1997 using nominal interest rates and the inflation rate for Argentina, Brazil and Mexico economies in order to examine fisher effect. According to the result of the study, The Fisher effect is valid for Brazil and Argentina.

Gül and Açıkalın (2007) tested the fisher effect for Turkey by using data over the period 1990-2007. Results of this study showed that the Fisher effect was valid for Turkey for the period examined.

Mishkin (1992) tried to Show the reason that there was powerful proof of a Fisher effect for some periods and not for others. At the end of study, he stood out that a Fisher effect could only come across in situation where inflation and interest rates displayed stochastic trends. 
Papers on the Fisher effect for examples of Organization for Economic Co-operation and Development countries have been examined by Mishkin (1984), Peng (1995) and MacDonald and Murphy (1989).

Mishkin (1984) examined the validity of Fisher effect for seven Organization for Economic Co-operation and Development countries over the period 1967:2-1979:2. At the end of his study, he reached the conclusion that there was a close relationship between nominal interest rates and expected rates of inflation for the UK, the US and Canada but weaker fisher effect for Germany, the Netherlands and Switzerland.

Peng (1995) examined the relationships between interest rates and expected inflation for the United Kingdom, for the United States of America, Japan, Germany and France over the period 1957-1994. By Johansen (1988) and Johansen and Juselius (1990) methodology, he reached the long-run relationship between expected inflation and interest rates for the United Kingdom, the United States of America and France. However, it was reached that Expected inflation was found to have a much weaker impact on interest rates in Germany and Japan.

Mac Donald and Murphy (1989) tested the Fisher effect for the period 1955 to 1986 for the United States of America, Canada and Belgium. In the result of study, null hypothesis of no co integration could not be rejected for all countries.

Beyer and et al. (2009) tested the Fisher Effect for 15 developed countries over the periods between 1957:Q1 and 2007:Q4 by using Johansen cointegration test and dynamic least squares. At the end of study, he reached the result that inflation effects to interest rates positively. And there is a cointegration relationships among variables.

Ito (2009) examined the validity of Fisher Effect for Japan Economy over the periods 1987:01 and 2006:06 by time series analysis. According to result, Fisher effect is valid for the period 1987:10 and 1991:06. For this period, there is a cointegration relationships and inflation effects to the interest rates. But theory is not valid for 1987:10 and 2006:06. In japan economy for the 1987:10 and 2006:06 periods, fisher effect and cointergration relationship is not met which means inflation and interest rates do not effect each other's.

Incekara et al. (2012) tested the fisher effect for the Turkish Economy. By using the Johansen Cointegration Analysis, they reached the result that for the period of 1989: Q1 and 2011:Q4, the Fisher effect was valid in Turkey.

Bayat (2012) examined the nominal interest rate and consumer price index for Turkey as a parallel of Fisher effect. At the end of study, He revealed that there is no Fisher effect for Turkey in examined period.

Chen (2015) tested the Fisher Effect Theory and Fisher Paradox for China Economy for 1980-2012. After conducting the Granger Causality Test of "Fisher Effect"they reached 
the result that China does not exist long- term stable relationship between interest rate and inflation rate.

Akıncı ve Yilmaz (2016) tested the Fisher effect for Turkish Economy over the periods 1980-2012. Johansen-Juselius cointegration test and Granger causality test is applied. Result of dynamic least squares analysis inflation rate, current account balance, external debt service, Money supply, exchange rate and process of economic growth have statistically significant effects on the interest rate.

\section{Econometric Analysis for China Economy}

In this part of study, the Fisher effect in China economy will be test by using ARDL bounds testing approach over the period 1996:01-2015:03. Nominal interest rates and inflation rates which were obtained from International Money Fund (IMF) and Organization for Economic Co-operation and Development (OECD) web page will be used as variables in the analysis. For empirical analysis, Şimşek and Kadılar's study (2006) has been used.

Table: 2

Symbol of Variables

\begin{tabular}{|l|l|}
\hline$R_{t}$ & Nominal Interest Rates \\
\hline$\pi_{t}$ & Inflation Rates \\
\hline$\eta_{t}$ & Error Term \\
\hline
\end{tabular}

Vector auto regression (VAR) is an econometric analysis used to get the linear interdependencies among multiple time series. Vector auto regression (VAR) models universalize the univariate auto regression (AR) models by letting for more than one evolving variable. In our study, equation is as given below.

$$
R_{t}=\gamma_{0}+\gamma_{1} \pi_{t}+\eta_{t}
$$

In equation (10), $R_{t}$ shows nominal interest rates, $\pi_{t}$ inflation rate which is based on gross national products deflator.

\subsection{Augmented Dickey Fuller Unit Root Test}

Before setting the logit model, we will examine if data lead to "spurious regression "problem or not by using Augmented Dickey Fuller unit root tests. Stationary of a time series means having a fixing variance and mean over time. In other words, a stationary time series is one whose statistical properties such as the mean, variance and autocorrelation, etc. are all constant over time (Gujarati, 1999: 712, 713). In the case of non-stationary series, time series includes the deterministic or stochastic trend. In this case, we can run into the spurious regression problem. Our Augmented Dickey Fuller equation below: 


$$
\begin{aligned}
& \Delta Y_{t}=\alpha+\beta t+\gamma Y_{t-1}+c \sum \Delta Y_{t-1}+u_{t} \\
& H_{0}: \gamma=0 \\
& \mathrm{H}_{1}: \gamma \neq 0
\end{aligned}
$$

If $\mathrm{H}_{0}$ is rejected, the variable $\mathrm{Y}$ is stationary at original level. If $\mathrm{H}_{0}$ hypothesis is not rejected, $\mathrm{Y}$ variable is no stationary. In this case, we take the first difference of the series to achieve stationary. Table 3 shows the result of Augmented Dickey Fuller unit root test.

Table: 3

\section{Results of Augmented Dickey Fuller Unit Root Result Test}

\begin{tabular}{|c|c|c|c|c|}
\hline Variables & Lag & ADF Values & Lag & First Differences \\
\hline$R_{t}$ & 1 & $-2.09 * *$ & 1 & $-8.44^{*}$ \\
\hline $\boldsymbol{\pi}$ & 3 & -1.17 & 3 & $-11.90^{*}$ \\
\hline
\end{tabular}

Note: (*) denote the rejection of the null hypothesis at first difference of variables for $1 \%$ level and (**) denote the rejection of the null hypothesis at level of variables for $5 \%$ level. McKinnon Critique values at $1 \%$ level and $5 \%$ level are respectively -3.421 and -2.312 .

It is understood from the Augmented Dickey Fuller result that is a stationary at level and $\boldsymbol{\pi}$ is stationary at first difference for $5 \%$ significant level.

\subsection{F Statistic for Determining Long Run Relationship and Johansen Co Integration Test} statistics.

Significance of lagged level relationship can be determined by calculating the $\mathrm{F}$

Null hypothesis refers if there is co-integration relationship among variables or not. It is shaped as below:

Ho: $\lambda 1=\lambda 2=0$

H1: $\lambda 1 \neq 0$, or $\lambda 2 \neq 0$ See Peseran et al. $(2001,8)$.

\begin{tabular}{|c|c|c|c|c|c|c|}
\hline \multicolumn{7}{|c|}{ The critical limit value } \\
\hline & \multicolumn{2}{|c|}{$10 \%$} & \multicolumn{2}{|c|}{$5 \%$} & \multicolumn{2}{|c|}{$1 \%$} \\
\hline $\mathrm{d}$ & $\mathrm{I}(0)$ & $\mathrm{I}(1)$ & $\mathrm{I}(0)$ & $\mathrm{I}(1)$ & $\mathrm{I}(0)$ & $\mathrm{I}(1)$ \\
\hline 1 & 4.61 & 4.96 & 4.80 & 6.20 & 8.41 & 8.75 \\
\hline \multirow{2}{*}{\multicolumn{7}{|c|}{ Calculated F statistic }} \\
\hline & \multicolumn{6}{|c|}{$F_{r} 19.130$} \\
\hline
\end{tabular}

Table: 4

F Statistic for Long Run Relationship

Firstly, F statistic was calculated under the condition that nominal interest rate is an independent variable. After that, inflation was accepted as an independent variable.

Johansen co integration test was developed Johansen (1988) and Johansen-Juselius (1990) to examine the existence of co integration relationship. Johansen methodology puts forward to test formulation as below: 


$$
\begin{aligned}
& \lambda_{\text {Trace }}(r)=-T \sum_{i=r+1}^{n}\left(\ln (1-) \lambda_{i}\right) \\
& \lambda_{\max \left(r_{1}, r+1\right)}=-T \ln \left(1-\lambda_{r+1}\right)
\end{aligned}
$$

....Based on Pesaran critical bounds vales if the calculated F statistics falls outside the critical bounds, a conclusive decision can be made regarding co integration without knowing the order of integration of the regresses. If the predicted $F$ statistic is higher than the upper bound of the critical values then the null hypothesis of no co integration is rejected. Alternatively, if the estimated $F$ statistic is lower than the lower bound of critical values, the null hypothesis of no co integration cannot be rejected (Hassan Ali, 2010: 18).

In the event of $\mathrm{F}$ statistic (19.130) is bigger than highest of critical (8.75) at $1 \%$ significant level, null hypothesis is rejected. That means there is a long run relationship among variables. In accordance with result, there is a long run relationship between interest rate and inflation. Result of Johansen co integration can be seen Table 5 below:

\section{Table: 5}

Johansen Co integration Results

\begin{tabular}{|c|c|c|c|}
\hline Null Hypothesis & Test Statistic & $1 \%$ Value & \\
\hline $\mathrm{H}_{0}$ Hipotezi & (LR) & 33.34 & \\
\hline $\mathrm{r}=0$ & 71.21 & 18.39 & 26.64 \\
\hline $\mathrm{r} \leq 1$ & 12.21 & 11.85 & \\
\hline
\end{tabular}

\subsection{ARDL Bounds Testing Approach}

The autoregressive distributed lag (ARDL) model was developed by Pesaran and Shin (1999), Pesaran et al. (2001) in order to consolidate I(0) and I(1) variables in same prediction under the assumption that all variables are stationary $\mathrm{I}(0)$, ordinary least square (OLS) is acceptable. However, if variables of model are non-stationary I(1) then it is preferable to do vector error correction model (VECM, Johanson Approach) as it is much simple model we can't predict.

We cannot estimate traditional ordinary least square on the variables in the event that any one of variable or all of variables are (1) because mentioned variable will not treat like constants which is required in OLS. But in this situation, ordinary least square erroneous Show higher $t$ values than it should be which means it causes a spurious result. When $R$ square of the analysis higher that the Durban Watson statistic, we face the spurious problem.

ARDL bounds testing involve two parts. In the first part, relationships among variables will be tested for long run by using equation (14) below:

$$
\Delta R_{t}=a_{0}+\sum_{i=1}^{p} b_{i} \Delta R_{t-i}+\sum_{i=0}^{p} c_{i} \Delta \pi_{t-i}+\lambda_{1} R_{t-1}+\lambda_{2} \pi_{t-1}+\varepsilon_{t}
$$

Afterwards, short run relationships will be examined by using equation (14). The best way to use ARDL bounds testing is that the ARDL does not need that all the variables under study must be integrated of the same order and it can be applied when the underlying 
variables are integrated of order one, order zero or fractionally integrated" (Belloumi, 2014: 19).

Table: 6

Selected ARDL (1,0)

\begin{tabular}{|c|c|c|}
\hline Variables & coefficient & t statistic \\
\hline$R_{t-1}$ & $0.621^{*}$ & 3.87 \\
\hline$\pi_{t-1}$ & $420.124^{*}$ & 3.07 \\
\hline $\mathrm{C}$ & 0.312 & -0.009 \\
\hline $\mathrm{LM}$ & & $2.02(0.721)$ \\
\hline
\end{tabular}

\subsection{Error Correction Model}

In order to provide the consistence of error correction model, coefficient should be negative. Result of error correction model is.

Table: 7

Result of Error Correction Model

\begin{tabular}{|c|c|c|}
\hline Variables & Coefficent & t statistic \\
\hline$\Delta \boldsymbol{\pi}_{t}$ & $374.214^{*}$ & 4.011 \\
\hline$E C_{t-1}$ & $-0,61^{*}$ & -6.21 \\
\hline
\end{tabular}

According to Table 7, the EC (Error correction) is statistically significant and negative. Coefficient of term is -0.61 which means that theoretically-driven approach beneficial for predicting both short and long terms effects of one-time series on another. Result means that $61 \%$ of the shock to the long run equilibrium disappears after one period.

Table: 8

ARDL Long Run Results

\begin{tabular}{|c|c|c|}
\hline Variables & Coefficent & t statistic \\
\hline$\pi_{t}$ & 711.12 & 4.12 \\
\hline $\mathrm{C}$ & -0.23 & -0.31 \\
\hline
\end{tabular}

According to obtained results in Table (8), long term inflation rate statistical has a strong and significant effect on nominal interest rates.

\section{Conclusion}

Investments and savings in China show a tendency decrease. As a result of this situation, growth rate and current account surplus decrease. Beside, China prevents the unemployment problem by implementing the policies related to labor-intensive investments. In order to increase of falling growth rate, Chine implemented the expansionary fiscal policy. Because of this fact that China faced the growing budget deficit and growing public debt burden. Before the empirical analysis, Theoretical background of Fisher effect was explained. Following, economic improvements in China economy was scrutinized by considering the regional issues. Study has been strengthened by literature survey which is including domestic and foreign literature. 
Altunöz, U. (2018), "Investigating the Presence of Fisher Effect

for the China Economy", Sosyoekonomi, Vol. 26(35), 27-40.

According to reported by the National Bureau of Statistics of China, Inflation Rate averaged 5.48\% from 1985 until 2016, reaching an all-time high of 28.40 in 1989. China is for this reason; Fisher effect has become more important issue for China.

In this paper, fisher the hypothesis of fisher was examined by Johansen co integration analysis and bound testing approach for the period between 1995:01-2013:03 for China. For this aim, nominal interest rates and inflation rate were used as variables. According to obtained results, coefficient of term is -0.61 which means that theoretically-driven approach beneficial for predicting both short and long terms effects of one-time series on another. Result means that $61 \%$ of the shock to the long run equilibrium disappears after one period.

It is concluded that the Fisher hypothesis is valid in China for the relevant terms. The results obtained from the study about fisher effect in China shows that nominal interest rate and inflation rate are co integrated. It is understood that the Fisher effect is supported for China Economy. Because of the fact that majority of studies doesn't support the Fisher effect, result of this paper become more important.

Three different conclusions can be drawn from the study. The first of these is that the monetary policies implemented in China could not be much more effective on long-term real interest rates. Second result is that according to the inflation expectations of economic agents, resources would be directed to the investments and mentioned relationships will be proportional. Last one is that inflationary press on the Chinese economy might be blocked by adjustments on interest rates.

\section{References}

Akınc1, M. \& Ö. Yılmaz (2016) "Enflasyon-Faiz Oranı Takası: Fisher Hipotezi Bağlamında Türkiye Ekonomisi İçin Dinamik En Küçük Kareler Yöntemi”, Sosyoekonomi, 24(27), 33-35.

Bayat, T. (2012), “Türkiye'de Fisher Etkisinin Geçerliliği: Doğrusal Olmayan Eşbütünleşme Yaklaşımı, Erciyes Üniversitesi IIIBF Dergisi, 38, 47-60.

Beyer, A. \& A.A. Haug \& W.G. Dewald (2009), "Structural Breaks, Cointegration and the Fisher Effect”, European Central Bank Working Paper, No: 1013.

Belloumi, M. (2012), "The relationship between Trade, FDI and Economic growth in Tunisia: An application of autoregressive distributed lag model", Presented at the 15th Annual Conference on Global Economic Analysis, Geneva, Switzerland.

Carneniro, F.G. \& J.A. Divino \& C.H. Rocha (2002), "Revisiting the Fisher Hypothesis for the Cases of Argentina, Brazil and Mexico", Applied Economics Letters, 9(2), 95-98.

Chen, C. (2015), “'Fisher Effect' Theory and 'Fisher Paradox' in China's Economy”, Open Journal of Social Sciences, 3, 80-85, doi: 10.4236/jss.2015.310012

Cooray, A. (2002), The Fisher Effect: a review of the literature, Sydney, NSW: Macquarie Univ., Dep. of Economics, 1-25.

Dritsakis, N. (2011), Demand for money in Hungary: An ARDL Approach, Department of Applied Informatics University of Macedonia Economics and Social Sciences.

Dutt, S. \& G. Ghosh (1995), “The Fisher Hypothesis: Examining the Canadian Experience”, Applied Economics, 27, 1025-1030. 
Eğilmez, M. (2015), Çin Ekonomisi, <http://www.mahfiegilmez.com/2015/08/cin-ekonomisi.html>, 02.07.2016.

Fama, E.F. (1975), "Short Term Interest Rates as Predictors of Inflation”, American Economic Review, 65, 269-282.

Fama, E. \& M.R. Gibbons (1982), "Inflation, Real Returns, and Capital Investment”, Journal of Monetary Economics, 9, 297-324.

Fisher, I. [1930] (1961), The Theory of Interest, New York: Macmillan.

Garcia, M.G.P. (1993), "The Fisher Effect in a Signal Extraction Framework: The Recent Brazilian Experience", Journal of Development Economics, 41, 71-93.

Gujarati, D.N. (1999), Temel Ekonometri, (Trans. Ü. Şenesen \& G.G. Şenesen), İstanbul, Literatür Yayınları.

Gül, E. \& S. Açıkalın (2007), “An Examination of the Fisher Hypothesis: The Case of Turkey”, Applied Economics, 99(1), 87-90.

Hassan, A. \& M. Hisham (2008), An Analysis of Growth and Inequality in Sudan: Cointegration and Causality Evidence (1956-2003), (March 2, 2008), Available at SSRN: <http://ssrn.com/abstract=1530403 orhttp://dx.doi.org/10.2139/ssrn.1530403>, 21.09.2016.

Hatemi, A. \& M. Irandoust (2008), "The Fisher Effect: A Kalman Filter Approach to Detecting Structural Change", Applied Economics Letters, 15(8), 619-624.

Hatemi, A. (2009), “The International Fisher Effect: Theory and Application”, Investment Management and Financial Innovations, 6(1), 117-121.

Huizinga, J. \& F.S. Mishkin (1986), "Monetary Policy Regime Shifts and the Unusual Behavior of Real Interest Rates", Carnegie-Rochester Conference Series on Public Policy, 24, 231274.

Incekara, A, \& S. Demez \& M. Ustaoğlu (2012), "Validity of Fisher effect for Turkish economy: Cointegration analysis", Procedia-Social and Behavioral Sciences, 58, 396-405.

Ito, T. (2009), "Fisher Hypothesis in Japan: Analysis of Long-Term Interest Rates under Different Monetary Policy Regimes", The World Economy, 32(7), 1019-1035.

Johansen, S. (1988), "Statistical analysis of cointegration vectors", Journal of Economic Dynamics and Control, 12(1), 231-54.

Johansen, S. \& K. Juselius (1990), "Maximum likelihood estimation and inference on cointegration with application to the demand for money", Oxford Bulletin of Economics and Statistics, 52, 69-206.

MacDonald, R. \& P.D. Murphy (1989), “Testing for the Long Run Relationship between Nominal Interest Rates and Inflation Using Cointegration Techniques", Applied Economics, 21, 439-447.

McKinnon, R.I. (1973), Money and Capital in Economic Development, Washington, DC: Brookings Institution.

Mishkin, F. (1984), “Are Real Interest Rates Equal across Countries? An Empirical Investigation of International Parity Conditions", Journal of Finance, 39, 1345-1357.

Mishkin, F.S. (1992), "Is the Fisher Effect for Real? A Reexamination of the Relationship between Inflation and Interest Rates", Journal of Monetary Economics, 30, 195-215.

Kandel, S. \& A. Ofer \& O. Sarig (1996), "Real Interest Rates and Inflation: An Ex-ante Empirical Analysis", Journal of Finance, 51, 205-225. 
Peng, W. (1995), “The Fisher Hypothesis and Inflation Persistence Evidence From Five Major Industiral Countries", IMF Working Paper, No. 95/118.

Pesaran, M.H. \& Y. Shin (1999), An Autoregressive Distributed Lag Modelling Approach to Cointegration Analysis, <http://www.econ.cam.ac.uk/faculty/pesaran/ardl.pdf>, 29.09.2013.

Pesaran, M.H. \& Y. Shin \& R. Smith (2001), "Bounds Testing Approaches to the Analysis of Level Relationship", Journal of Applied Econometrics, 16(3), 289-326.

Phylaktis, K. \& D. Blake (1993), “The Fisher Hypothesis: Evidence from Three High Inflation Economies", Weltwirtschaftliches Archiv, 129, 591-599.

Shaw, E. (1973), Financial Deepening in Economic Development, New York: Oxford University Press. 